\title{
Pemanfaatan Limbah Ternak Kelinci untuk Pembuatan Pupuk Organik Padat dan Cair
}

\author{
Nurhidayati, Abdul Basit \\ Departemen Agroteknologi, Fakultas Pertanian, Universitas Islam Malang, Lowokwaru, Malang, Jawa Timur, \\ Indonesia
}

Submitted: 09 Januari 2020; Revised: 24 September 2020; Accepted: 02 November 2020

$\begin{array}{ll}\text { Kata Kunci: } & \text { Abstrak Universitas Islam Malang memiliki desa binaan yang terletak di Desa } \\ \text { Kompos cair } & \text { Codo, Kecamatan Wajak, Kabupaten Malang. Mayoritas masyarakat desa ini }\end{array}$

Kompos cair

Kotoran kelinci

Kompos padat

Kualitas pupuk organik

Keywords:

Liquid compost

Rabbit dung

Solid compost

Quality of

organic

fertilizer beraktivitas di bidang pertanian dan peternakan. Beberapa tahun terakhir, peternak di Desa Codo mengembangkan peternakan kelinci hingga terbentuk kelompok peternak kelinci. Namun, peningkatan jumlah peternak kelinci memunculkan permasalahan baru, yaitu melimpahnya limbah kotoran kelinci. Penanganan yang tepat diperlukan untuk mengatasi masalah limbah tersebut. Hal ini mendorong UIM untuk melaksanakan program pengabdian masyarakat dalam rangka transfer teknologi pembuatan pupuk organik padat dan cair yang berasal dari kotoran kelinci. Kegiatan dibagi dalam tiga tahap pelaksanaan, yaitu penyuluhan tentang pentingnya penggunaan pupuk organik untuk kesuburan tanah dan diskusi perihal berbagai masalah kesuburan tanah di lahan pertanian. Kegiatan kedua dan ketiga adalah pelatihan pembuatan kompos padat dan cair. Kegiatan ini dimulai pada Agustus-November 2019 dengan melibatkan mahasiswa sebagai fasilitator. Hasil kegiatan menunjukkan bahwa pelatihan pemanfaatan kotoran kelinci sebagai pupuk organik padat dan cair dapat memberikan pengetahuan tambahan bagi peternak kelinci. Peternak kelinci juga mendapatkan informasi tentang kualitas kompos kotoran kelinci dan kompos campuran serta dampaknya terhadap kesuburan lahan pertanian. Luaran kegiatan ini adalah $83 \%$ masyarakat telah mampu membuat pupuk organik dari kotoran kelinci dan menghasilkan produk pupuk organik padat dan cair dengan komposisi kimia yang berbeda.

Abstract University of Islam Malang has a sister village program in Codo Village, Wajak District, Malang Regency which is recognized as a high agricultural and animal husbandry potential. In recent years, farmers in Codo village have developed rabbit farms. Further, they had a rabbit breeder group. However, the increasing number of rabbit breeders raises new problems, namely the abundance of rabbit dung. Proper strategy is needed to solve the problem. This encourages UIM to conduct a community service program on technology transfer regarding making solid and liquid organic fertilizers from rabbit dung in Codo Village. The activity focused on three tasks. First, the counseling and training for making solid and liquid compost. Second, the counseling about the importance of using organic fertilizers for soil fertility. Lastly, the discussions on various soil fertility issues related to agricultural land. This community service activity was initiated in August-

ISSN 2460-9447 (print), ISSN 2541-5883 (online)

${ }^{*}$ Corresponding author : Nurhidayati

Departemen Agroteknologi, Fakultas Pertanian, Universitas Islam Malang, Jalan Mayjen Haryono No.193, Dinoyo, Kec. Lowokwaru, Kota Malang 65144, Jawa Timur,, Indonesia

Email: nurhidayati@unisma.ac.id 
November 2019 and successfully carried out with the help of students as facilitators. The use of rabbit dung as a solid and liquid organic fertilizer provided additional knowledge for rabbit breeders. They got information about the quality of rabbit manure compost and its impact on agricultural land. As a result of this activity, $83 \%$ of the community has been able to make organic fertilizer based on rabbit dung and produce solid and liquid organic fertilizer products with different chemical compositions.

\section{PENDAHULUAN}

Desa Codo adalah salah satu desa di Kecamatan Wajak, Kabupaten Malang, Provinsi Jawa Timur yang memiliki potensi cukup tinggi di bidang pertanian dan peternakan. Pada umumnya petani di Desa Codo menerapkan sistem pertanian terpadu dengan mengombinasikan kegiatan pertanian dan peternakan. Jumlah ternak yang dominan di Desa Codo adalah sapi, yaitu 496 ekor. Adapun ternak kambing berjumlah 260 ekor, ayam kampung 5.261 ekor, dan ayam ras 20.000 ekor (Profil Desa Codo, 2018). Pada dua tahun terakhir ini, masyarakat Desa Codo mengembangkan peternakan kelinci. Sejumlah $60 \mathrm{KK}$ beternak kelinci dengan rata-rata jumlah kelinci per kandang 30-50 ekor. Enam puluh KK tersebut dibagi dalam dua kelompok peternak kelinci yang masing-masing beranggotakan tiga puluh orang.

Produktivitas peternak kelinci di Desa Codo cukup baik begitu juga dengan pemasarannya. Akan tetapi, limbah kotoran ternak yang dihasilkan masih menjadi masalah dalam hal pengelolaannya. Kotoran kelinci yang melimpah di sekitar kandang menunjukkan bahwa siklus aliran energi dari peternakan ke pertanian belum berlangsung dengan baik meskipun peternak kelinci di Desa Codo juga petani.

Pemahaman tentang konsep pertanian terpadu yang masih rendah memengaruhi terjadinya pencemaran lingkungan perairan di sekitar wilayah Desa Codo. Hasil survei dan wawancara awal yang dilakukan oleh pelaksana pengabdian dengan peternak menunjukkan bahwa petani di Desa Codo belum memiliki pemahaman tentang manajemen limbah ternak yang tepat. Oleh karena itu, kotoran kelinci yang melimpah belum dimanfaatkan dengan baik dan hanya ditimbun di sekitar kandang.

Solusi yang ditawarkan untuk mengatasi permasalahan tersebut adalah dengan memperkenalkan pemanfaatan limbah ternak kelinci menjadi pupuk organik kepada masyarakat melalui kegiatan pengabdian. Kegiatan pengabdian yang dilakukan berupa penyuluhan tentang pentingnya aplikasi pupuk organik untuk mempertahankan kesuburan tanah di lahan pertanian di Desa Codo, Kecamatan Wajak. Kegiatan ini bertujuan untuk meningkatkan pemahaman masyarakat tentang pembuatan pupuk organik dari limbah pertanian dan peternakan serta meningkatkan kesadaran masyarakat tentang pentingnya pupuk organik untuk mempertahankan kesuburan tanah.

Pupuk organik adalah hasil dekomposisi bahanbahan organik oleh mikroorganisme yang menghasilkan unsur hara yang dibutuhkan untuk pertumbuhan dan perkembangan tanaman. Pupuk organik berperan penting dalam meningkatkan kesuburan fisik, kimia, dan biologi tanah. Aplikasi pupuk organik dapat meningkatkan efisiensi penggunaan pupuk anorganik karena pupuk organik bersifat lepas lambat (slow release). Kualitas dan komposisi pupuk organik bervariasi tergantung pada bahan dasar kompos dan proses pembuatannya (Supartha et al., 2012; Sazzad et al., 2013; Hartatik et al., 2015).

Salah satu jenis pupuk organik adalah pupuk kandang. Komposisi kimia pupuk kandang berbedabeda tergantung pada jenis ternak, umur ternak, jenis pakan, jumlah amparan, cara penanganan, dan penyimpanan. Aplikasi pupuk kandang berpengaruh positif terhadap sifat fisik dan kimiawi tanah serta mendorong kehidupan mikroorganisme tanah sehingga memengaruhi kesuburan tanah secara keseluruhan (Sajimin, 2011; Dinesh et al., 2012). Perubahan tingkat kesuburan tanah karena aplikasi pupuk organik terbukti dapat meningkatkan pertumbuhan dan hasil dari berbagai tanaman hortikultura dan pangan. Peningkatan hasil yang diperoleh tergantung pada jenis kotoran ternak yang digunakan (Niassy \& Diarra, 2012).

Beberapa hasil penelitian melaporkan bahwa aplikasi pupuk kotoran kelinci, baik tunggal maupun yang dikombinasikan dengan pupuk anorganik NPK, dapat meningkatkan pertumbuhan dan kandungan klorofil tanaman kailan (Anggrayni et al., 2013), meningkatkan bobot biji per tanaman sorgum dan rendemen biji (Ruminta et al., 2017), dan meningkatkan pertumbuhan serta hasil tanaman paprika (Aderemi et al., 2020).

\section{METODE}

Kegiatan pengabdian kepada masyarakat ini dilaksanakan pada 10 Agustus sampai dengan 15 
November 2019. Kegiatan berlokasi di Desa Codo, Kecamatan Wajak, Kabupaten Malang, Provinsi Jawa Timur. Target peserta dalam kegiatan ini adalah peternak kelinci dan kelompok tani. Kegiatan dilaksanakan dalam tiga tahap, yaitu (a) observasi dan sosialisasi; (b) pelatihan dan pendampingan praktik pembuatan pupuk organik padat dan cair; serta (c) penyuluhan tentang pentingnya bahan organik untuk mempertahankan kesuburan tanah.

\subsection{Observasi dan Sosialisasi}

Tahap awal kegiatan ini adalah observasi kondisi lingkungan, potensi peternakan dan pertanian, serta jumlah peternak kelinci dan potensi limbah ternak kelinci yang dihasilkan di Desa Codo. Hasil observasi digunakan untuk menentukan kegiatan pengabdian yang akan dilakukan serta untuk mengatasi permasalahan yang ditemukan terkait dengan aktivitas pertanian dan peternakan. Kegiatan selanjutnya adalah sosialisasi kepada para peternak kelinci dan petani di Desa Codo, Kecamatan Wajak, Kabupaten Malang tentang kegiatan pengabdian ini. Sosialisasi pertama dilakukan dengan Kepala Desa Codo untuk menginformasikan pelaksanaan kegiatan. Selanjutnya, Kepala Desa Codo menyampaikan kepada para peternak kelinci dan petani tentang rencana kegiatan yang akan dilaksanakan selama satu minggu (10-17 Agustus 2019).

\subsection{Pelatihan dan Pendampingan Praktik Pembuatan Pupuk Organik Padat dan Cair}

Sebelum melaksanakan kegiatan pelatihan dan pendampingan praktik pembuatan pupuk organik, tim dengan dibantu oleh mahasiswa dan masyarakat menyediakan alat dan bahan yang dibutuhkan untuk pembuatan pupuk organik padat dan cair. Alat-alat yang dibutuhkan adalah terpal, sekop, drum kapasitas 200 liter, aerator, dan selang plastik. Adapun bahan yang dibutuhkan adalah limbah pertanian berupa residu panen dan serasah dedaunan serta kotoran kelinci.

Setelah alat dan bahan siap, pengabdi dan mahasiswa bersama kelompok peternak kelinci sasaran melaksanakan pelatihan dan praktik langsung pembuatan pupuk kompos padat menggunakan bahanbahan yang telah disiapkan. Komposisi campuran untuk pembuatan pupuk organik padat adalah 2:1:1 (kotoran kelinci:jerami/dedaunan:sisa sayuran). Serasah dedaunan dan sisa sayuran dihaluskan dengan cara dicacah kemudian dicampur dengan kotoran kelinci. Pencampuran ini berfungsi untuk mempercepat proses pengomposan limbah tanaman pangan, seperti jerami dan daun jagung yang sulit terdekomposisi. Campuran bahan tersebut kemudian disiram dengan larutan mikroorganisme efektif untuk merangsang perkembangan organisme yang berperan sebagai dekomposer. Kadar air dalam proses pengomposan dipertahankan pada kisaran 30-40\%.

Pembuatan kompos padat membutuhkan waktu satu bulan. Pemantauan pengomposan dilakukan dengan mengukur suhu bahan organik yang dikomposkan menggunakan termometer. Pembuatan pupuk kompos cair dilakukan setelah pupuk kompos padat matang. Alat yang digunakan dalam proses pembuatan pupuk kompos cair adalah drum dan aerator untuk menyuplai oksigen. Selain itu, digunakan juga Effective Microorganism dan molase. Proses ini berlangsung selama sepuluh hari. Hasil yang ditargetkan pada tahapan ini adalah beberapa petani mampu membuat pupuk organik padat dan cair.

\subsection{Penyuluhan Pentingnya Pupuk Organik untuk Mempertahankan Kesuburan Tanah}

Tahap ketiga dari rangkaian kegiatan pengabdian kepada masyarakat ini adalah penyuluhan tentang pentingnya pupuk organik untuk mempertahankan kesuburan tanah. Penyuluhan dilakukan melalui penyampaian materi oleh dosen pengabdi dan diskusi terkait dengan masalah kesuburan tanah di lahan pertanian Desa Codo. Kegiatan ini juga melibatkan mahasiswa dalam persiapan acara penyuluhan dan sebagai moderator.

\section{HASIL DAN PEMBAHASAN}

\subsection{Pelatihan Pembuatan Pupuk Organik Padat Berbahan Dasar Kotoran Kelinci}

Proses pembuatan pupuk organik padat berlangsung selama satu bulan. Setelah satu bulan, bahan organik tersebut siap digunakan sebagai pupuk kompos.

Kompos padat yang sudah matang berwarna cokelat tua sampai kehitaman dan bertekstur lebih halus daripada tekstur pada awal pengomposan. Hasil analisis komposisi kimia pupuk organik yang berasal dari kotoran kelinci dan campuran bahan organik disajikan pada Tabel 1.

Tabel 1. Hasil Analisis Kimia Pupuk Organik Padat yang Berasal dari Campuran Bahan Organik dan Kotoran Kelinci Dibandingkan dengan Kotoran Kelinci Tanpa Campuran

\begin{tabular}{ccc}
\hline \multirow{2}{*}{ Parameter Kimia } & \multicolumn{2}{c}{ Komposisi Kimia } \\
\cline { 2 - 3 } & Kompos & Kotoran \\
& Campuran & Kelinci \\
\hline C-organik (\%) & 24,65 & 20,45 \\
BO (\%) & 31,31 & 25,97 \\
N total (\%) & 1,02 & 1,26 \\
C: N rasio & 24,16 & 16,25 \\
P (\%) & 0,62 & 0,71 \\
K (\%) & 0,85 & 0,57 \\
pH & 6,63 & 6,56
\end{tabular}

3.2 Pelatihan Pembuatan Pupuk Organik Cair (POC) dari Kompos Campuran dan Kotoran Kelinci 
Kegiatan pelatihan pembuatan pupuk organik cair dari kompos campuran dan kotoran kelinci dilakukan setelah pembuatan pupuk organik padat yang berasal dari campuran kotoran kelinci dan limbah pertanian. Proses pembuatan pupuk organik cair ini diawali dengan mempersiapkan peralatan yang dibutuhkan, yaitu drum ukuran 200 liter, selang plastik, dan aerator. Adapun bahan yang dibutuhkan adalah kompos campuran dan kotoran kelinci yang sudah matang. Setelah itu, bahan kompos campuran dan kotoran kelinci ditimbang sebanyak $25 \mathrm{~kg}$ lalu dimasukkan ke dalam kain kasa, diikat dengan kuat, dan dimasukkan ke dalam drum yang telah diisi air sampai $5 \mathrm{~cm}$ di bawah permukaan drum.

Setiap hari, drum dialiri oksigen menggunakan aerator. Proses ini berlangsung selama sepuluh hari. Setelah proses fermentasi selesai, pupuk organik cair siap digunakan. Pupuk organik cair yang sudah matang dan siap digunakan berwarna cokelat kemerahan menyerupai warna teh. Perbedaan kepekatan pupuk cair menunjukkan perbedaan komposisi kimia atau konsentrasi hara yang terkandung di dalamnya. Hasil analisis komposisi kimia pupuk disajikan pada Tabel 2. Tabel 2. Hasil Analisis Kimia Pupuk Organik Cair yang Berasal dari Campuran Bahan Organik dan Kotoran Kelinci Dibandingkan dengan Kotoran Kelinci Tanpa Campuran

\begin{tabular}{lcc}
\hline \multirow{2}{*}{ Parameter Kimia } & \multicolumn{2}{c}{ Komposisi Kimia } \\
\cline { 2 - 3 } & $\begin{array}{c}\text { Kompos } \\
\text { Campuran }\end{array}$ & $\begin{array}{c}\text { Kotoran } \\
\text { Kelinci }\end{array}$ \\
\hline Electricity & 3,08 & 3,42 \\
Conductivity (EC) & & \\
$(\mathrm{mS})$ & & \\
$\mathrm{N}$ total $(\%)$ & 0,0106 & 0,0196 \\
$\mathrm{P}(\%)$ & 0,0060 & 0,0103 \\
$\mathrm{~K}(\%)$ & 0,078 & 0,012 \\
$\mathrm{pH}$ & 6,67 & 6,61 \\
\hline
\end{tabular}

3.3 Penyuluhan Pentingnya Bahan Organik untuk Mempertahankan Kesuburan Tanah

Kegiatan penyuluhan dilaksanakan untuk meningkatkan pemahaman petani tentang pentingnya bahan organik dalam tanah untuk mempertahankan kesuburan tanah. Kegiatan yang dilaksanakan di Balai Desa Codo, Kecamatan Wajak ini dihadiri oleh anggota kelompok tani dan peternak.

Peserta sangat antusias mendengarkan materi penyuluhan karena selama ini mereka masih menerapkan sistem budi daya tanaman secara konvensional tanpa menggunakan bahan organik. Setelah mengikuti kegiatan ini, peserta diharapkan dapat menerapkan pengetahuan dan keterampilan membuat pupuk kompos dari limbah peternakan, khususnya dari kotoran kelinci. Pupuk organik yang dihasilkan kemudian dapat diaplikasikan ke lahan pertanian di Desa Codo, Kecamatan Wajak. Produk pupuk organik cair yang dihasilkan dari kegiatan ini terlihat.

Havlin et al. (2005) menyatakan bahwa bahan organik sangat penting untuk mempertahankan kesuburan fisik, kimia, dan biologi tanah. Aplikasi bahan organik ke dalam tanah dapat meningkatkan kemantapan agregat tanah karena bahan organik menghasilkan senyawa humik yang berperan dalam proses agregasi tanah (Castro Filho et al., 2002; Chilom et al., 2009), menurunkan berat isi tanah (Wolf \& Snyder, 2003), serta memperbaiki porositas tanah dan mengurangi kepadatan tanah sehingga kecepatan infiltrasi tanah meningkat (Funderburg, 2001; Nurhidayati et al., 2011; Nurhidayati et al., 2015). Selain berpengaruh terhadap kondisi fisik tanah, aplikasi bahan organik juga mampu meningkatkan populasi mikroorganisme dalam tanah sehingga proses dekomposisi, mineralisasi, dan berbagai proses lainnya dapat berjalan dengan baik. Penambahan pupuk organik yang menghasilkan humus dapat pula meningkatkan Kapasitas Tukar Kation (KTK) tanah (Parfit et al., 1995; Caravaca et al., 1999; Saidi, 2012; Nurhidayati, 2017).

Produk yang dihasilkan dari kegiatan ini adalah pupuk organik padat dan cair dari bahan kotoran kelinci. Hasil analisis kimia menunjukkan bahwa kandungan hara $\mathrm{N}$ dan $\mathrm{P}$ dalam kompos campuran lebih rendah daripada kompos dari kotoran kelinci. Adapun kandungan kalium kompos campuran lebih tinggi daripada kotoran kelinci. Hal ini menunjukkan bahwa perbedaan komposisi bahan organik menentukan komposisi kimia pupuk organik yang dihasilkan (Nurhidayati et al., 2017). Meskipun kadar hara $\mathrm{N}$ dan $\mathrm{P}$ dalam kompos campuran lebih rendah, efek jangka panjangnya lebih besar karena akan menghasilkan humus di dalam tanah. Selain itu, kandungan C-organik kompos campuran lebih tinggi daripada kompos dari kotoran kelinci. Bahan organik tanah yang stabil, seperti humus, berdampak positif, yaitu dapat memperbaiki struktur tanah (Centre for Recycled Organiks in A griculture, NSW Industry and Investment, 2010) dan meningkatkan kandungan koloid tanah sehingga KTK tanah meningkat (Havlin et al., 2005; Nurhidayati, 2017).

Hasil analisis kimia pupuk cair yang berasal dari kotoran kelinci dan kompos campuran menunjukkan bahwa kandungan $\mathrm{N}$ dan $\mathrm{P}$ serta konduktivitas listrik pupuk cair yang berasal dari kotoran kelinci lebih tinggi daripada pupuk cair yang berasal dari kompos campuran. Adapun kandungan $\mathrm{K}$ dan $\mathrm{pH}$ pupuk cair kotoran kelinci lebih rendah (Tabel 2). Hasil analisis kimia pupuk cair dan kompos padat menunjukkan bahwa pembuatan pupuk cair dengan kotoran kelinci dan kompos campuran menurunkan kandungan $\mathrm{N}, \mathrm{P}$, 
dan K dalam kedua pupuk organik tersebut (Tabel 1 dan Tabel 2).

Pupuk organik cair dapat langsung diserap oleh tanaman, sedangkan pupuk organik padat membutuhkan waktu untuk bisa diserap oleh tanaman melalui proses mineralisasi. Sazzad et al. (2013) menjelaskan bahwa pupuk organik padat termasuk pupuk yang lepas lambat (slow release) sehingga pelepasan hara berlangsung secara bertahap. Pupuk lepas lambat memberikan efek positif dalam budi daya tanaman, yaitu meningkatkan efisiensi pemupukan dan mengurangi hilangnya hara karena pencucian. Khalid et al. (2013) melaporkan bahwa aplikasi pupuk yang lepas lambat dalam bentuk kompos padat meningkatkan hasil tanaman zucchini.

Berdasarkan hasil kuesioner dari tiga puluh responden (petani dan peternak yang tergabung dalam kelompok peternak kelinci) diketahui bahwa $78 \%$ responden memahami bahwa kegiatan pengelolaan limbah ternak kelinci ini penting. Sebanyak $90 \%$ menyatakan bahwa mereka membutuhkan informasi tentang cara pembuatan pupuk organik dari kotoran kelinci (Tabel 3). Dengan demikian, kegiatan ini berdampak pada peningkatan pengetahuan petani dan peternak dalam pemanfaatan limbah pertanian dan peternakan menjadi produk yang bermanfaat untuk mempertahankan kesuburan tanah.

Hasil evaluasi akhir yang dilakukan setelah pelatihan menunjukkan 25 orang peternak kelinci telah memahami cara membuat pupuk organik dengan bahan dasar kotoran kelinci. Angka tersebut menunjukkan peningkatan sebanyak 21 orang dari baseline yang berjumlah 4 orang (13,3\% dari total jumlah anggota) yang telah mengetahui cara memanfaatkan kotoran kelinci sebagai pupuk organik (Tabel 3) (Gambar 5).

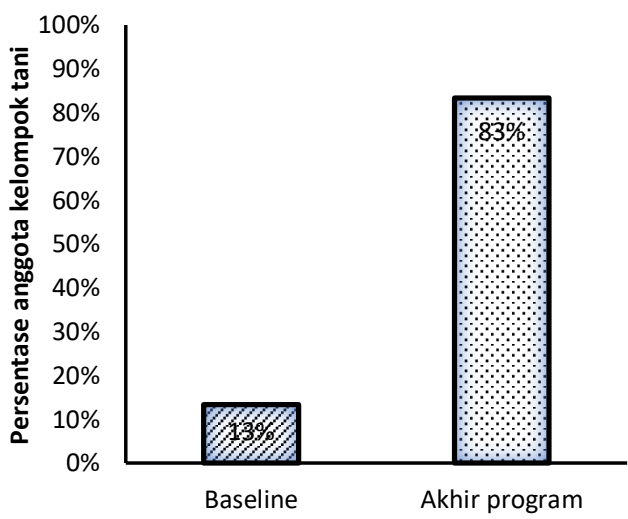

Gambar 5. Hasil evaluasi tingkat pemahaman petani dan peternak dalam membuat pupuk organik yang berasal dari kotoran kelinci
Tabel 3. Kuesioner pemanfaatan kotoran kelinci untuk pembuatan pupuk organik

\begin{tabular}{llc}
\hline No. & \multicolumn{1}{c}{ Pernyataan } & Persentase \\
\hline 1. & $\begin{array}{l}\text { Daerah tempat tinggal saya } \\
\text { memiliki permasalahan } \\
\text { tentang tanah pertaniannya. }\end{array}$ & \\
2. & $\begin{array}{l}\text { Daerah tempat tinggal saya } \\
\text { memiliki permasalahan }\end{array}$ & \\
& tentang pengelolaan limbah \\
& ternak kelinci. \\
Menurut saya kegiatan & $78 \%$ \\
pengelolaan limbah kotoran & \\
kelinci adalah penting. & $\begin{array}{l}\text { Saya telah mengetahui cara } \\
\text { pengelolaan kotoran kelinci. }\end{array}$ \\
Saya telah mengetahui bahwa \\
kotoran kelinci dapat \\
dimanfaatkan sebagai pupuk \\
organik padat dan cair. \\
Saya memerlukan informasi \\
tentang cara membuat pupuk \\
organik yang berasal dari \\
kotoran kelinci.
\end{tabular}

Berdasarkan analisis data kuesioner diketahui bahwa peternak kelinci yang sekaligus sebagai petani memiliki permasalahan perihal kesuburan tanah yang harus segera diatasi. Permasalahan tersebut berkaitan dengan menurunnya kandungan bahan organik tanah yang mengakibatkan penurunan produktivitas tanaman. Solusi yang dapat dilakukan adalah penambahan pupuk organik ke dalam tanah. Oleh karena itu, pelatihan pembuatan pupuk organik dari kotoran kelinci ini sangat membantu petani dalam menyelesaikan permasalahan yang dihadapi.

Keberlanjutan kegiatan pembuatan pupuk organik melalui pengomposan di Desa Codo, Kecamatan Wajak membutuhkan koordinasi antaranggota kelompok tani dan peternak, terutama dalam manajemen bahan baku. Kelompok petani dan peternak harus membentuk organisasi yang mewadahi kegiatan produksi pupuk organik dan mengoordinasi pengumpulan bahan baku. Manajemen bahan baku bisa dilakukan dengan sistem barter bahan. Petani mengirimkan bahan limbah pertanian dan peternak mengirimkan kotoran kelinci kemudian diproses menjadi pupuk organik dan dikembalikan lagi kepada petani anggota.

\section{KESIMPULAN}

Kegiatan pelatihan pembuatan pupuk organik berbahan dasar kotoran kelinci dan penyuluhan tentang pentingnya bahan organik untuk lahan pertanian di Desa Codo, Kecamatan Wajak mampu meningkatkan pengetahuan dan keterampilan petani serta peternak dalam pembuatan pupuk organik dengan memanfaatkan limbah peternakan dan pertanian. Sebanyak $83 \%$ peternak kelinci telah memahami cara membuat pupuk organik padat dan cair menggunakan 
kotoran kelinci. Kegiatan penyuluhan juga meningkatkan pemahaman petani dan peternak kelinci di Desa Codo tentang pentingnya bahan organik untuk kesuburan tanah.

\section{UCAPAN TERIMA KASIH}

Penulis menyampaikan terima kasih kepada Universitas Islam Malang yang telah mendanai kegiatan pengabdian kepada masyarakat ini melalui program Hibah Institusi Unisma (Hi-ma) LPPM Unisma. Terima kasih juga disampaikan kepada mitra, yaitu kelompok petani-peternak kelinci di Desa Codo, Kecamatan Malang dan mahasiswa Unisma yang sedang melaksanakan kegiatan KKN di Desa Codo pada periode Agustus 2019 atas bantuan yang diberikan selama pelaksanaan kegiatan pengabdian kepada masyarakat ini.

\section{REFERENSI}

Aderemi, F.T., Adewoye, A.A , Aderemi, A.M., Shaib-Rahim, H.O., \& Roberts, A.E. (2020). Comparative effects of rabbits dung, NPK 15:15:15 and cow dung on the growth and yield of pepper. International Journal of Innovative Research and Advanced Studies (IJIRAS) 7 (8), $163-165$.

Anggrayni, Y., Bandem, P.D., \& Sirojul, A.M. (2013). Pengaruh pemberian pupuk kotoran kelinci terhadap pertumbuhan dan hasil tanaman kailan pada tanah Alluvial. Jurnal Sains Mahasiswa Pertanian, 2(1), 5.

Caravaca, F., Lax, A., \& Albaladejo,J. (1999). Organic matter, nutrient contents and cation exchange capacity in fine fractions from semiarid calcareous soils. Geoderma, 93(1999): 161176.

Castro Filho, C., Lourenco, \& A., Guimaraes, F. (2002). Aggregate stability under different soil management systems in red latosol in the state of Parana, Brazil. Soil \& Tillage Research, 65(2002), 45-51.

Centre for Recycled Organics in A griculture, NSW Industry and Investment. (2010). Using Recycled Organics And Manures In Grain-Cropping Systems. Recycled Organik Fertiliser Fact Sheet. Grain Research \& Developments Corporation (GRDC). www.dpi.nsw.gov.au/research/centres/croa

Chilom, G., Bruns, A.S., \& Rice, J.A. (2009). Aggregation of humic acid in solution: Contributions of different fractions. Organic Geochemistry, 40 (4) : 455-460.

Dinesh, R., Srinivasan, V., Ganeshamuthry, A.N., \& Hamza, S. (2012). Effect of Organic Fertilizers on Biological Parameters Influencing Soil Quality and Productivity. In Rajeev Pratap Singh (Ed.), Organic Fertilizers Types, Production And Environmental Impact. ISBN: 978-1-62081-457-
4 (eBook). Nova Science Publishers, Inc. New York.

Funderburg, E.D. (2001). What does organic matter do in soil? https://www.noble.org/news/publications/agnews-and-views/2001/august/what-doesorganic-matter-do-in-soil/

Hartatik, W., Husnain, \& Widowati L., R. (2015). Peranan pupuk organik dalam peningkatan produktivitas tanah dan tanaman. Jurnal Sumberdaya Lahan, 9(2), 107-120.ARG

Havlin, J.L, Beaton, J.D., Tisdale, A.L., \& Nelson, W.L. (2005). Soil Fertility and Fertilizers ( $7^{\text {th }}$ ed.). Pearson Prentice Hall. Upper Saddle River, New Jersey.

Khalid, A., Mehdi, M., Imane, T.A., Kenny, L. \& Soudi, B. (2013). Effect of slow release organik nitrogen fertilizer combined with compost on soil fertility, yield and quality of organik zucchini in sandy Soil. Conference Paper June 2013. https://doi.org/10.13140/2.1.4396.5442

Niassy, S. \& Diarra, K. (2012). Effects of Organic Inputs in Urban Agriculture and Their Optimization For Poverty Alleviation In Senegal, West-Africa. In Rajeev Pratap Singh, Organik Fertilizers Types, Production And Environmental Impact. ISBN: 978-1-62081-4574 (eBook). Nova Science Publishers, Inc. New York.

Nurhidayati, Arisoesilaningsih, E., Soeprayogo, D., \& Hairiah K. (2011). Long-term impact of conventional soil management to earthworm diversity and density on sugarcane plantation in East Java. Journal of Nature Studies, 10(2),1625.

Nurhidayati, Suprayogo, D, Arisoesilaningsih, E., \& Hairiah, K. (2015). Improvement of physical and biological quality of soil in a sugarcane plantation through the management of organic matter input. Journal of Agricultural Science and Technology A, 5(2015), 316-324. https://doi.org/10.17265/2161-6256/ 2015.05.002

Nurhidayati. (2017). Kesuburan dan Kesehatan Tanah: Suatu Pengantar Penilaia Kualitas Tanah Menuju Pertanian Berkelanjutan. ISBN: 978602-1507-68-1. Intimedia.

Nurhidayati, Ali, U., \& Murwani, I. (2017). Chemical composition of vermicompost made from organik wastes through the vermicomposting and composting with the addition of fish meal and egg shells flour. Journal of Pure and Applied Chemistry Research, 6(2), 127-136. https://doi.org/10.21776/ub.jpacr.2017. 006.02.309

Parfit, R.L., Giltrap, D.J., \& Whitton, J.S. (1995). Contribution of organic matter and clay minerals to the cation exchange capacity of soil. Communications in Soil Science and Plant Analysis, 26(9-10):1343--1355. 
Profil Desa Codo. (2018). Profil Desa Codo, Kecamatan Wajak, Kabupaten Malang, Provinsi Jawa Timur.

Ruminta A., Wahyudin, M.L., \& Hanifa. (2017). Pengaruh pupuk N,P,K dan pupuk organik kelinci terhadap hasil sorgum (Sorghum bicolor [Linn.] Moench) di lahan tadah hujan Jatinangor. Jurnal Kultivasi, 16(2), 362-367.

Saidi, D. (2012). Importance and role of cation exchange capacity on the physicals properties of the cheliff saline soils (Algeria). Procedia Engineering, 33(2012), 435-449.

Sajimin. (2011). Medicago sativa (Alfalfa) sebagai Tanaman pakan Ternak Harapan di Indonesia. Balai Penelitian Ternak, Bogor.

Sazzad, M.H., Islam, M.T., \& Chowdhury, F. (2013). A Review \& Outlook of Slow-Release Fertilizer: A breakthrough product for agronomy \& horticulture. ISBN: 978-3-659-41507-4. LAP Lambert Academic Publishing.

Supartha, I.Y.N., Wijana, G., \& Adnyana, G.M. (2012). Aplikasi jenis pupuk organik pada tanaman padi system pertanian organik. Jurnal Agrotektropika, 1(2), 98-106.

Wolf, B. \& Snyder, G. (2003). Sustainable Soils: The Place of Organic Matter in Sustaining Soils and Their Productivity. Food Product Press. An Imprint of The Haworth Press. 